\title{
WYBRANE ELEMENTY KULTURY ORGANIZACYJNEJ ORGANIZACJI CHIŃSKICH W PERSPEKTYWIE SPÓJNOŚCI STRUKTUR PROCESOWO-WIRTUALNYCH
}

https://doi.org/10.33141/po.2019.05.05

\section{Michał Flieger, Marcin Flieger}

\section{Wprowadzenie}

$\mathbf{Z}$ miany zachodzące w rzeczywistości funkcjonowania współczesnych organizacji niosą ze sobą konsekwencje, które wywierają istotny wpływ na sposób, w jaki menedżerowie podchodzą do projektowania zarówno struktur organizacyjnych, jak i innych elementów organizacji. Globalne podejście do klientów, ich zmieniająca się charakterystyka, a także ciągła presja dotycząca wzrostu sprawności i efektywności funkcjonowania organizacji skutkuje poszukiwaniem nowych rozwiązań nie tylko wewnątrz organizacji ale i w jej relacjach $\mathrm{z}$ innymi uczestnikami rynku (Sułkowski, 2013). W ostatnich dekadach otoczenie organizacji uległo głębokiej transformacji, a kluczową rolę odgrywa wielokierunkowa współzależność podmiotów (Mayne i in., 2003; Czakon, 2012). Coraz częściej poszukiwane są alternatywne sposoby funkcjonowania stanowiące niejako antidotum na ograniczenia wynikające $\mathrm{z}$ zastosowania tradycyjnych struktur organizacyjnych.

Te nowe rozwiązania dotyczą przede wszystkim możliwości wykorzystania perspektywy procesowej, której reguły stosowane są zarówno $\mathrm{w}$ konfiguracji i podziale zasobów wewnętrznych organizacji, jak i w tworzeniu mniej lub bardziej trwałych relacji z firmami kooperującymi. Współcześnie struktury procesowe oraz te, które powstały poprzez zastosowanie założeń koncepcji procesowej (struktury wirtualne), są aktywnie wykorzystywane przez organizacje poszukujące trwałych przewag konkurencyjnych.

Zastosowaniu struktur wirtualnych sprzyjają tendencje otwarcia ekonomiczno-gospodarczego rejonów świata, które jeszcze niedawno były trudno dostępne dla organizacji funkcjonujących na terenie państw rozwiniętych (Borowski, 2015). Takie otwarcie zwiększa możliwości wykorzystania niedostępnych dotąd zasobów dla tworzenia wartości dodanych dla klientów, co stanowi nowe szanse dla wielu przedsięwzięć ponadnarodowych.

Powyższe prawidłowości powodują jednak, że pojawiają się niezwykle ważne i aktualne wyzwania, przed jakimi stoją menedżerowie decydujący się na wykorzystanie zasobów umiejscowionych $w$ innych rejonach świata (Pierścionek, 2003). Zgodnie z zasadami koncepcji spójności (o której poniżej), konieczne jest zachowanie harmonii pomiędzy tzw. płaszczyznami spójności organizacyjnej. Oznacza to, że organizacje współpracujące ze sobą w ramach nowoczesnych struktur wirtualnych stoją przed koniecznością harmonizacji wielu elementów ich funkcjonowania w celu zapewnienia trwałej, efektywnej, skutecznej i nieproblemowej współpracy.

Jednym z elementów, który w dużym stopniu wpływa na charakter współpracy pomiędzy organizacjami z różnych rejonów świata, są różnice oraz podobieństwa w kulturze organizacyjnej (Flieger, Turek, 2016). Świadomość owych różnic jest punktem wyjścia dla zdiagnozowania charakteru kultury organizacyjnej firm kooperujących w celu harmonijnego dostosowania się i trwałej współpracy.

Jednym z kluczowych obszarów gospodarczych współczesnego świata jest rejon Chin, który to kraj odgrywa dużą rolę w funkcjonowaniu współczesnych organizacji. Stopniowe znoszenie barier politycznych spowodowało, że wykorzystanie potencjału organizacji chińskich jest szansą oraz wyzwaniem dla organizacji z innych rejonów świata, także organizacji polskich. Istotnym problemem jednak jest fakt, że organizacje te są w niewielkim stopniu rozpoznane w aspekcie specyfiki ich funkcjonowania, a także mało znane są cechy ich kultury organizacyjnej.

Stąd celem głównym niniejszego opracowania jest przedstawienie wyników badań dotyczących obszaru norm i wartości, a także poziomu założeń kulturowych dominujących w organizacjach chińskich. Celem pomocniczym jest przedstawienie podstawowych założeń koncepcji spójności organizacyjnej w strukturach wirtualnych. Teza niniejszego opracowania mówi, że możliwe jest wskazanie cech charakterystycznych kultury organizacyjnej organizacji chińskich, przy czym znajomość tych cech może przyczynić się do ułatwienia procesu dostosowania się organizacji z innych rejonów świata (także polskich) do tych różnic. Pozwoli to na lepsze wykorzystanie potencjału organizacji chińskich podczas tworzenia przewag konkurencyjnych w strukturach wirtualnych.

Należy zwrócić uwagę, że powyższy problem badawczy, a także cele i tezy opracowania są nie tylko nader aktualne, ale mają również duże znaczenie dla praktyków zarządzania. Wyniki przedstawionych badań posiadają znaczny potencjał aplikacyjny i mogą być bezpośrednio wykorzystywane $\mathrm{w}$ procesie osiągania spójności organizacyjnej w ramach mechanizmów współpracy w strukturach wirtualnych ${ }^{1}$. 


\section{Koncepcja spójności jako podstawa rozważań}

$\mathbf{R}$ ozważania prowadzone w niniejszym opracowaniu oparte są na podstawie naukowej stworzonej przez koncepcję spójności. Koncepcja ta opracowana została przez jednego $\mathrm{z}$ autorów i zakłada konieczność harmonizacji różnych, zdefiniowanych płaszczyzn spójności w celu optymalizacji skuteczności i efektywności funkcjonowania organizacji (Flieger, 2016, s. 21-31). Brak świadomości dotyczącej koncepcji spójności w organizacjach oraz zaniedbania płynące $z$ braku lub niepełnej harmonizacji owych płaszczyzn skutkują poważnymi dysfunkcjami organizacyjnymi, stąd zagadnienie spójności organizacyjnej jest jednym $\mathrm{z}$ kluczowych we współczesnym zarządzaniu organizacjami. Należy w tym miejscu zaznaczyć, że koncepcja spójności, o której tutaj mowa, stanowi nową koncepcję zarządzania, która jednocześnie służy wypełnieniu luki badawczej. Spójność organizacyjna rozumiana jest kompleksowo i dotyczy wszystkich płaszczyzn funkcjonowania organizacji. Oczywiście samo pojęcie spójności pojawia się w różnych publikacjach, jednak zwykle dotyczy wąskich aspektów, na których koncentrują się autorzy, np. spójności strategii, spójności wizerunku (Obłój, 2009; Flieger, 2014).

W ogólnym ujęciu, na strategicznym poziomie zarządzania, obejmującym całą organizację, wyróżnić można trzy płaszczyzny spójności (Flieger, 2017a). Pierwsza $\mathrm{z}$ nich tworzona jest przez koncepcje zarządzania oraz metody zarządzania, które muszą tworzyć spójny system. W ogólnym zarysie chodzi o to, że zastosowanie pewnych koncepcji zarządzania implikuje konieczność zastosowania założeń koncepcji komplementarnych, ale dodatkowo konieczne jest zastosowanie określonych metod zarządzania, które swoimi założeniami wspierają z kolei założenia i mechanizmy płynące z przyjętych wcześniej koncepcji zarządzania. Kolejną płaszczyznę spójności tworzy system zarządzania oraz przyjęte struktury organizacyjne. Każda struktura organizacyjna, a w szczególności struktury nowoczesne, zakładające wykorzystanie założeń organizacji procesowej, wymaga dopasowanego sposobu zarządzania. Ostatnią płaszczyzną spójności jest połączenie dwóch poprzednich z charakterem zasobów ludzkich zatrudnionych w danej organizacji. Odpowiednio sprofilowane koncepcje, metody, struktury oraz styl zarządzania skutkują jasno określonymi wymogami dotyczącymi cech i profilu zasobów ludzkich w danej organizacji. Powoduje to konieczność zarówno odpowiedniego doboru pracowników, ich szkolenia, jak i profilowania zasobów ludzkich, które dotychczas funkcjonują w organizacji. Dopiero dopasowanie wszystkich wymienionych wcześniej elementów zapewnia osiągnięcie spójności organizacyjnej, która na dodatek musi być cały czas monitorowana i optymalizowana.

\section{Rola kultury organizacyjnej w zachowaniu spójności organizacyjnej}

$\mathbf{P}$ łaszczyzny spójności mogą być wyodrębniane na poziomie strategicznym, taktycznym oraz operacyjnym funkcjonowania organizacji. Takie ujęcie pozwala na zapewnienie spójności na każdym poziomie zarządzania, a płaszczyzny spójności poziomów niższych muszą wpisywać się w logikę poziomów wyższych. W strukturach procesowych, a w szczególności w strukturach wirtualnych, niezbędne jest wskazanie konieczności poszukiwania płaszczyzn spójności zapewniających sprawną współpracę pomiędzy poszczególnymi uczestnikami struktury. Konieczność taka w tym przypadku potęgowana jest faktem, że w strukturach wirtualnych współpracujące firmy pochodzą zwykle $\mathrm{z}$ krajów znajdujących się $\mathrm{w}$ różnych rejonach świata, a co za tym idzie, mogą pochodzić z obszarów o znacznych różnicach kulturowych. Różnice te w naturalny sposób przenoszone są na różnice w sposobach funkcjonowania oraz $\mathrm{w}$ sposobach postrzegania rzeczywistości i reagowania na nią. Bardzo ważnym elementem jest zatem świadomość występujących różnic oraz wypracowanie mechanizmów współpracy, które te różnice uwzględniają.

Elementem kluczowym sprawnej współpracy jest tutaj świadomość oraz dopasowanie się uczestników struktury wirtualnej do sposobów funkcjonowania partnerów wynikających z ich kultury organizacyjnej, która jest podstawowym nośnikiem wyżej opisanych różnic. Zatem kultura organizacyjna to ważny element stanowiący płaszczyznę spójności organizacyjnej w strukturach wirtualnych. W ten właśnie nurt wpisują się rozważania oraz wyniki badań przedstawione w niniejszym opracowaniu, ponieważ znajomość cech charakterystycznych organizacji chińskich jest punktem wyjścia do opracowania mechanizmów współpracy z tymi organizacjami i skutecznego wykorzystania ich potencjału. Należy zaznaczyć, że w niniejszym opracowaniu autorzy odnieśli się do poziomu norm i wartości oraz założeń kulturowych, poświęcając poziomowi artefaktów oddzielne opracowanie ${ }^{2}$.

\section{Zarys istoty struktur wirtualnych w aspekcie spójności organizacyjnej}

$\mathbf{Z}$ większająca się dostępność zasobów zlokalizowanych w różnych miejscach świata, a także konieczność poszukiwania kolejnych sposobów maksymalizacji wartości dodanych dla klientów organizacji powoduje, że coraz bardziej powszechne staje się wykorzystanie struktur organizacyjnych, które umożliwiają nawiązanie współpracy $\mathrm{z}$ organizacjami na całym świecie $\mathrm{w}$ celu wytworzenia określonego wyrobu. W ten sposób możliwe staje się skoordynowanie w jednym czasie i w jednym przedsięwzięciu zasobów znajdujących się w każdym miejscu i ograniczenie lokalizacyjne przestaje mieć znaczenie w konfiguracji struktury organizacyjnej.

Podstawą struktur wirtualnych jest koncepcja procesowa. W strukturach tych poszczególne gniazda tworzone są przez organizacje, które dobierane są na zasadzie posiadanych kluczowych czynników sukcesu (KCS) (Flieger, 2017b). Za organizacje posiadające KCS uważa się takie, które z pewnych względów są najlepsze w branży. Stąd przyjmuje się, że w ramach struktury wirtualnej współpracują ze sobą organizacje, które są najlepsze w skali rynku globalnego, a zatem wartość dodana tworzona przez posiadaczy KCS powinna być najwyższa. W ten sposób 
organizacja wirtualna tworzy przewagę konkurencyjną, która pozwala jej na wygenerowanie korzyści zarówno dla klienta, jak i dla uczestników takiej organizacji.

$\mathrm{W}$ aspekcie koncepcji spójności integrator organizacji wirtualnej stoi przed problemem harmonizacji współpracy pomiędzy poszczególnymi gniazdami (tworzonymi przez firmy z KCS) (Perechuda, 2000). Jednym z kluczowych elementów wpływających na możliwości skutecznej i efektywnej współpracy pomiędzy organizacjami pochodzącymi z różnych rejonów świata jest kultura organizacyjna. Stąd każdy integrator organizacji wirtualnej musi mieć świadomość różnic kulturowych, a także powinien posiadać wiedzę dotyczącą cech kultury organizacyjnej tych organizacji, które będą tworzyć w danym przypadku organizację wirtualną (Flieger, 2012). Taka wiedza potrzebna jest również szeregowym uczestnikom organizacji wirtualnej, ponieważ to oni kontaktują się bezpośrednio i współpracują na bieżąco z gniazdami będącymi ich dostawcami oraz klientami wewnętrznymi. W przypadku KCS znajdujących się na terenie Chin niniejsze opracowanie dostarcza takim organizacjom cennej wiedzy umożliwiającej zapewnienie skutecznej i harmonijnej współpracy oraz efektywnego wykorzystanie KCS firm Państwa Środka.

\section{Metoda badawcza}

D a realizacji powyższych celów oraz weryfikacji postawionych tez badawczych przeprowadzono badania o charakterze zarówno literaturowym, jak i empirycznym. Badania literatury przedmiotu pozwoliły na dokonanie syntetycznego przedstawienia zagadnień związanych z istotą koncepcji spójności oraz podstawowych mechanizmów struktur wirtualnych. Najważniejszą jednak częścią prezentowanych osiągnięć badawczych są wyniki badań empirycznych, które przeprowadzone zostały $\mathrm{w}$ ramach dwumiesięcznego stażu naukowego $\mathrm{w}$ organizacjach chińskich, głównie $\mathrm{z}$ rejonu miasta Guiyang i najbliższych okolic, znajdujących się w prowincji Gouizhou. W ramach prowadzonych badań dokonano identyfikacji cech charakterystycznych poziomu norm i wartości, a także założeń kulturowych organizacji chińskich, przy czym badania dotyczyły zarówno cech faktycznych, jak i takich cech, które badani pracownicy uważaliby za właściwe (zbadano zatem stan faktyczny oraz pożądany z perspektywy pracowników chińskich) ${ }^{3}$. Takie ujęcie problemu może pozwolić na dostosowanie się do różnic kulturowych, a także na poszukiwanie takich rozwiązań kulturowych, które są szczególnie pożądane przez pracowników z organizacji chińskich.

Grupa badawcza liczyła ponad 600 pracowników różnych szczebli pracujących w badanych organizacjach, przy czym zdecydowana większość badanych pracowników pochodziła ze szczebla wykonawczego. Około 150 badanych osób to pracownicy zajmujący stanowiska kierownicze. Grupa badawcza to pracownicy 36 organizacji, z których 20 należało do sektora usługowego (handlowo-gastronomicznego), a 16 do sektora produkcyjnego (produkcja żywności, wyrobów chemicznych oraz odzieży).
Zdecydowaną większość firm zaliczyć można do grupy MŚP - 22 badanych organizacji. Resztę stanowiły przedsiębiorstwa duże, pochodzące $\mathrm{w}$ całości $\mathrm{z}$ sektora produkcyjnego.

Dobór organizacji był celowo zróżnicowany - przebadano zarówno organizacje o charakterze produkcyjnym, jak i organizacje usługowe, różnych branż oraz wielkości. Wszystkie organizacje były organizacjami gospodarczymi - nie badano organizacji publicznych, ponieważ tworzenie wartości dodanych w strukturach wirtualnych odniesiono do wzajemnej współpracy jednostek gospodarczych. Należy przy tym podkreślić, że ze względu na specyficzny ustrój polityczny Państwa Środka badaniu specyfiki funkcjonowania organizacji publicznych należałoby poświęcić odrębne, szczegółowe badania, co może wskazywać kierunki dalszych poszukiwań.

Badania przeprowadzono $\mathrm{w}$ okresie listopada i grudnia 2017 roku z wykorzystaniem formularza ankiety zawierającej głównie pytania otwarte. Taki charakter pytań pozwolił na uzyskanie szerokiego zakresu odpowiedzi i na swobodę wypowiedzi osób ankietowanych, co jest zaletą stosowania takiej metody. Jego wadą natomiast jest ryzyko otrzymania zbyt szerokiego zakresu odpowiedzi, co może utrudniać analizę i porządkowanie danych. Ankiety przybrały formę zarówno fizyczną, jak i elektroniczną i były w pełni anonimowe, co zwiększyło prawdopodobieństwo uzyskania prawdziwych opinii respondentów. Każdorazowo ankiety poprzedzone były krótkim wykładem wyjaśniającym badanej grupie pracowników, czego dotyczy ankieta, jaki jest jej cel oraz jaka jest istota badanych elementów kultury organizacyjnej. Pozwoliło to na zwiększenie jakości uzyskanych wyników badań.

Dodatkowo należy wskazać na charakter wizyty badawczej $\mathrm{w}$ badanych organizacjach. Badacze, po wcześniejszym uzyskaniu zgody i wsparcia dyrekcji, uzyskiwali wstęp do badanych organizacji jako przedstawiciele nauki poszukujący danych pozwalających na realizację celów naukowych. Dzięki temu wizyty badawcze w organizacji miały charakter neutralny, pozwalający na zwiększenie obiektywności uzyskanych danych. Dodatkowo, wsparcie dyrekcji sprzyjało skrupulatności i szczegółowości uzyskiwanych odpowiedzi.

Kwestionariusz ankiety zawierał pytanie otwarte o artefakty językowe, behawioralne oraz rzeczowe ${ }^{4}$, o normy i wartości dominujące w badanych organizacjach oraz o założenia kulturowe zidentyfikowane przez badanych. Taki sposób sformułowania pytań sprzyjał swobodzie wypowiedzi badanych pracowników. Jednocześnie przeprowadzone wcześniej wykłady wyjaśniające pozwoliły na odpowiednie przygotowanie ankietowanych w zakresie poprawnej interpretacji pytań umożliwiającej dostarczenie właściwych danych. Badani wypełniali formularze w języku angielskim (często przy wykorzystaniu translatorów elektronicznych, ponieważ nie znali tego języka), a następnie odpowiedzi zostały pogrupowane przez badaczy tak, aby można było ustalić częstotliwość występowania określonej cechy w badanej próbie. W wynikach badań prezentowanych $\mathrm{w}$ niniejszym opracowaniu ujęto tylko te cechy, które wskazane zostały przez ponad 50\% 
badanych. Przyjęto, że jeżeli dana cecha wskazana została przez ponad połowę ankietowanych, należy ją uznać za opisującą badany obszar rzetelnie. Zrezygnowano jednocześnie z podawania szczegółowych wartości ilościowych oraz procentowych przy poszczególnych cechach zawartych $w$ tabelach wynikowych. Zestawienia przedstawione w tabelach 1-3 są wynikiem powyższych analiz oraz założeń metodycznych.

\section{Charakterystyka poziomu norm i wartości organizacji chińskich - wyniki badań}

ak wspomniano wyżej, badaniu poddano poziom norm i wartości, a także poziom założeń kulturowych organizacji chińskich. Należy zaznaczyć, że badano zarówno stan istniejący, jak i stan oczekiwany przez pracowników badanych organizacji. W ten sposób zgromadzone wyniki pozwalają z jednej strony dostosować się do różnic kulturowych i wypracować mechanizmy współpracy, które uwzględniają potencjalne preferencje pracowników z drugiej strony. Zatem zarówno integratorzy, jak i firmy kooperujące z firmami chińskimi mogą wykorzystać niniejsze wyniki badań nie tylko do lepszego rozpoznania problemu, ale i do wypracowania skutecznych sposobów współpracy, uwzględniając kierunki pożądane przez firmy chińskie 5 .

Wyniki badań w zakresie norm i wartości charakteryzujących organizacje chińskie przedstawiono w tabeli 1. Tabela ta zawiera odpowiedzi uzyskane przynajmniej w 50\% przypadków.

Jak pokazują wyniki badań przestawione w tabeli 1, w obszarze norm i wartości organizacje chińskie cechują się silną tendencją autokratyczną. Pracownicy podlegają ścisłym regułom oraz normom zachowania i nie mają w zasadzie możliwości wyrażania swoich opinii. Dominujące normy związane są $\mathrm{z}$ posłuszeństwem i bezrefleksyjnym wykonywaniem poleceń. Ewentualne opinie pracowników są ignorowane, stąd przełożeni poświęcają pracownikom niewiele czasu i uwagi. W konsekwencji pracownicy nie czują się częścią organizacji i nie czują do niej szacunku. Pomimo takiej sytuacji pracowników normą jest unikanie jawnego pokazywania niezadowolenia przez pracowników, którzy oficjalnie nie narzekają na panujące warunki. Pracownicy chińscy są raczej introwertyczni oraz unikają obrażania innych. Wysoko cenione są symbole oraz ceremonie organizacyjne.

W obszarze wartości organizacyjnych dominuje pieniądz, władza, zysk oraz interes indywidualny jednostki. Tradycyjnie ważna jest jednak rodzina i więzi krwi, zatem pojawić może się ewentualny nepotyzm. Ważna jest skromność, grzeczność oraz szacunek osobisty. Wyrażając swoje uwagi ogólne, badani pracownicy zwracali uwagę na dużą różnorodność norm i wartości wynikające bardzo często $\mathrm{z}$ dużych różnic religijnych mających miejsce w Chinach. Często także pracownicy nie mieli świadomości norm i wartości charakterystycznych dla ich organizacji.

Kolejnym badanym obszarem było wskazanie tych norm i wartości, które są oczekiwane przez pracowników chińskich. Wyniki badań wskazane przez co najmniej $50 \%$ respondentów przedstawione zostały w tabeli 2 . Tabela wskazuje jednoznacznie kierunki zmian kultury organizacyjnej, które oczekiwane są przez pracowników w Chinach. Wśród norm i wartości dominują potrzeby związane z podmiotowością pracowników, czyli potrzeba szacunku, uznania, uwagi, możliwości wyrażania opinii. Ponadto wyraźnie widać potrzeby dotyczące poczucia przynależności do grupy, identyfikacji z organizacją, zaufania i możliwości długofalowego rozwoju. Badani pracownicy zwracali też uwagę na potrzebę elastyczności myślenia i działania.

W obszarze wartości okazuje się, że badani pracownicy wykazują dużą tendencję ku wartościom uniwersalnym związanym z uczciwością, szczerością, otwartością, tolerancją, sprawiedliwością oraz przyzwoitością w postępowaniu. Widoczna jest także negacja dominującej roli pieniądza jako wartości nadrzędnej i chęć powrotu do wartości o charakterze duchowym. Wśród uwag ogólnych na pierwsze miejsce wysuwa się konieczność

Tabela 1. Obszar norm i wartości w organizacjach chińskich

\begin{tabular}{|c|c|c|}
\hline Normy istniejące & Wartości istniejące & Uwagi ogólne \\
\hline $\begin{array}{l}\text { Ciężka praca, kolektywizm, indywidualizm interesów, unikanie ryzyka, } \\
\text { ochrona społeczna, brak wizji długookresowej, rygorystyczne zasady } \\
\text { pracy, decydujące zdanie dyrekcji, łapówki, brak długoterminowej } \\
\text { perspektywy wzrostu zarobków, nieśmiałość, introwertyzm, rygorystyczne } \\
\text { normy, ostentacyjna wyższość nad klasą niższą (uboższymi), nierzadkie } \\
\text { lenistwo, naruszanie norm i zasad, korupcja polityczna, trudności } \\
\text { w akceptowaniu nowości, ważne rytuały i ceremonie, unikanie obrażania } \\
\text { współpracowników, brak narzekań, biurokracja, pracownicy nie wyrażają } \\
\text { swoich opinii, ignorowanie opinii i norm pracowników, dyscyplina } \\
\text { i posłuszeństwo, brak elastyczności, niechęć dzielenia się z pracownikami, } \\
\text { stosowanie wszelkich środków na ograniczenie kosztów, poleganie na } \\
\text { własnych umiejętnościach, brak indywidualizmu, oszustwa (materiałowe), } \\
\text { brak czasu i chęci ze strony przełożonych na komunikację, system nagród } \\
\text { i kar, podlizywanie się dyrekcji, brak szacunku dla organizacji ze strony } \\
\text { pracowników, brak konsultacji decyzji z pracownikami }\end{array}$ & $\begin{array}{l}\text { Dominująca rola pieniądza, cele } \\
\text { i efektywność organizacji nieistotne, } \\
\text { szybki zysk, racjonalizm, kluczowy } \\
\text { motywator to pensja, władza, } \\
\text { reputacja, rodzina, szacunek } \\
\text { dla starszych, zysk, zachowanie } \\
\text { harmonii, lojalność, grzeczność, } \\
\text { waga relacji interpersonalnych, } \\
\text { umiejętność zachowania tajemnicy } \\
\text { służbowej, punktualność, } \\
\text { skromność, dominuje interes } \\
\text { jednostki, szacunek dla klienta, } \\
\text { obecność w organizacji (brak } \\
\text { zwolnień), skromność, stabilizacja, } \\
\text { bezwarunkowe posłuszeństwo }\end{array}$ & $\begin{array}{l}\text { Trudne do sprecyzowania, } \\
\text { niejasne, różna religia } \\
\text { różnicuje pracowników, często } \\
\text { normy i wartości pozostają } \\
\text { w sprzeczności z pożądanymi } \\
\text { przez organizacje, duże } \\
\text { różnice norm i wartości } \\
\text { w jednej organizacji (np. } \\
\text { w poszczególnych wydziałach), } \\
\text { normy i wartości trudne } \\
\text { do rozpoznania przez } \\
\text { obcokrajowców, brak CSR, } \\
\text { zróżnicowanie religijne powoduje } \\
\text { różnorodność norm i wartości, } \\
\text { często „brak” norm i wartości }\end{array}$ \\
\hline
\end{tabular}

Źródto: opracowanie własne 
Tabela 2. Normy i wartości oczekiwane przez pracowników

\begin{tabular}{|c|c|c|}
\hline Normy oczekiwane & Wartości oczekiwane & Uwagi \\
\hline $\begin{array}{l}\text { Szacunek dla przekonań innych, poczucie } \\
\text { przynależności do firmy, poufność i zaufanie, } \\
\text { psychologiczna identyfikacja z firmą, szacunek } \\
\text { dla pracowników, wspólnota celów, gotowość do } \\
\text { podejmowania ryzyka, długofalowa perspektywa } \\
\text { rozwoju, akceptacja zmian, elastyczność, działanie } \\
\text { dla zysków długookresowych, możliwość } \\
\text { wyrażania opinii przez pracowników, zjednoczenie } \\
\text { pracowników, postawy proaktywne }\end{array}$ & $\begin{array}{l}\text { Służenie społeczeństwu (np. CSR), } \\
\text { tolerancja dla różnic, potępienie } \\
\text { łapownictwa, entuzjazm, otwartość, } \\
\text { tolerancja, empowerment, zrozumienie, } \\
\text { koegzystencja, sprawiedliwość, } \\
\text { przyzwoitość, uczciwość, powrót do } \\
\text { wartości tradycyjnych (nie tylko pieniądz), } \\
\text { wartości duchowe, entuzjazm, szczerość, } \\
\text { solidarność, otwartość, pomoc }\end{array}$ & $\begin{array}{l}\text { Jasne i powszechne normy standardowe dla } \\
\text { wszystkich, zrozumienie norm i wartości } \\
\text { przez pracowników, silniejsze normy } \\
\text { i wartości, więcej kontaktów z zagranicą } \\
\text { dla zrozumienia różnic kulturowych, } \\
\text { popularyzacja norm i wartości wśród } \\
\text { pracowników, dopasowanie norm i wartości } \\
\text { do różnic religijnych }\end{array}$ \\
\hline
\end{tabular}

Źródto: opracowanie własne

Tabela 3. Założenia kulturowe oraz oczekiwane kierunki zmian

Założenia kulturowe

Niechęć i obawa przez wygłaszaniem własnych opinii i przemyśleń, duża waga hierarchii, duża waga relacji interpersonalnych, relacje formalne odgrywają rolę drugorzędną, posłuszeństwo względem formalnych przełożonych, konserwatyzm myślenia i postępowania, radość z prostoty życia, waga harmonii w relacjach, duże znaczenie tradycji, duże znaczenie rodziny i historii, unikanie niepewności, szacunek dla władzy, wielość znaczeń (wieloznaczność), rozłam pomiędzy tradycją a nowoczesnością, prawo silniejszego, duża rola moralności religijnej, zaangażowanie społeczne, brak relacji z przełożonymi, słuchanie przełożonych, szacunek dla starszych i dla autorytetów, waga zaufania osobistego, strach przed odpowiedzialnością, komunikacja zależna od relacji osobistych, kultura wymagań od instytucji oraz rządu, dyskryminacja płci, orientacji seksualnych, pracoholizm
Kierunki zmian założeń kulturowych

Otwarta komunikacja i umiejętność wyrażania własnych opinii, zrozumienie i szacunek dla różnorodności, równość, wzrost znaczenia relacji zawodowych ponad osobiste, mniej rozkazodawstwa, podmiotowość pracowników, szacunek dla innych kultur, integracja kulturowa w organizacjach, brak naruszania założeń kulturowych pracowników, brak dyskryminacji płci, mniejsza rola hierarchii, dostosowanie do różnorodności, promocja kulturowej integracji, koncentracja na pracy i relacjach służbowych, wprowadzenie ideologii firmowej, otwartość

w komunikacji oraz jej zintensyfikowanie, uczciwe traktowanie i eliminacja preferowania w ramach koneksji, większa decyzyjność, innowacyjność, większa rola etyki, lojalność względem organizacji, otwartość, praca w grupach, równość

Źródło: opracowanie własne

stworzenia oraz zakorzenienia wśród pracowników spójnego systemu jasnych norm i wartości, które akceptowane będą przez większość pracowników. Pracownicy zwracają też uwagę na konieczność częstych kontaktów $\mathrm{z}$ zagranicą $\mathrm{w}$ celu zrozumienia i akceptacji różnic. Ta ostatnia uwaga związana jest $\mathrm{z}$ faktem, że pomimo otwarcia granic Chiny są wciąż krajem dość hermetycznym, co nie sprzyja zrozumieniu i akceptacji odmienności kulturowych.

Wskazane w tabeli 2 normy i wartości oczekiwane mają szczególne znaczenie dla organizacji kooperujących z organizacjami chińskimi, ponieważ pozwalają na trafną identyfikację kierunków, w których modelowane powinny być mechanizmy współpracy. Z drugiej strony, przedstawione wcześniej wyniki badań (tab. 1) nakazują dużą ostrożność i szczególną uwagę przede wszystkim w okresie nawiązywania współpracy i na pierwszych jej etapach. Wyniki badań pokazują jednoznacznie, że zachowanie spójności organizacyjnej w omawianych obszarach wymaga szczególnej uwagi i dochowania niezwykłej staranności dla skutecznej i efektywnej współpracy.

\section{Poziom założeń kulturowych}

K olejnym obszarem poddanym badaniu był obszar założeń kulturowych, których znajomość ma kluczowe znaczenie dla zrozumienia specyfiki funkcjonowania organizacji danego regionu. Założenia kulturowe są również tym elementem, z którego bezpośrednio po- chodzi wiele cech charakterystycznych poziomu norm i wartości, zatem zrozumienie założeń jest niezbędne dla zrozumienia przyczyn zjawisk zachodzących w organizacjach i w dalszej kolejności dla wypracowania mechanizmów współpracy zapewniających spójność organizacji wirtualnej.

Dodatkowo, przy opracowaniu mechanizmów współpracy istotna jest znajomość oczekiwań pracowników dotyczących potencjalnych kierunków zmian. Chodzi o to, że pracownicy mogą nie być zadowoleni z poszczególnych uświadamianych elementów założeń kulturowych i chcieliby niektóre $\mathrm{z}$ nich zmienić. Kierunki tych zmian dodatkowo mogą ułatwić organizacjom z zewnątrz dopasowanie się do oczekiwań pracowników, co w konsekwencji może sprzyjać wzrostowi poziomu spójności organizacyjnej. W tabeli 3 przedstawiono założenia kulturowe cechujące badane organizacje chińskie, jak również oczekiwane kierunki zmian wskazane przez co najmniej 50\% respondentów.

Jak pokazują wyniki przedstawione w tabeli 3, założenia kulturowe organizacji chińskich pozwalają na dość jednoznaczne zdefiniowanie dominujących w tych organizacjach mechanizmów. Przede wszystkim wyłania się obraz organizacji wysoce hierarchicznej z silnym podporządkowaniem pracowników, którzy pozbawieni są jakiejkolwiek swobody wyrażania swoich opinii. Rola pracownika sprowadza się zatem do biernego i posłusznego wykonawcy. Pracownicy nie nawiązują bliższych relacji $\mathrm{z}$ przełożonymi i cechują 
się brakiem gotowości do samodzielnych działań i do podejmowania odpowiedzialności. Dużą rolę odgrywają stosunki nieformalne, które często są podstawą zaufania i współpracy. Źródłem autorytetu jest wiek i doświadczenie pracowników, dużą rolę odgrywa tradycja oraz rodzina.

Analizując kierunki zmian oczekiwanych przez pracowników, można zauważyć, że są one konsekwencją cech pojawiających się w opisie przedstawionym powyżej. Oznacza to, że pracownicy nie czują się dobrze w sytuacji faktycznej i wskazywane przez nich kierunki zmian to $\mathrm{w}$ istocie zanegowanie tej sytuacji. Przyglądając się wynikom z tabeli 3, należy wskazać, że pracownicy oczekują zmian w kierunku eliminacji rozkazodawstwa i przedmiotowego traktowania na rzecz większej decyzyjności, możliwości wygłaszania własnych opinii, a także wzrostu znaczenia obiektywnych i uczciwych relacji formalnych. Pracownicy zwracają też uwagę na konieczność większej tolerancji dla różnic kulturowych i religijnych, przestrzeganie zasad moralnych oraz potrzebę większej przynależności i lojalności względem organizacji.

\section{Podsumowanie}

W ypracowanie mechanizmów współpracy w ramach struktur wirtualnych wymaga określenia specyfiki funkcjonowania organizacji wchodzących w jej skład w celu realizacji założeń płynących z koncepcji spójności organizacyjnej. Omówione powyżej wyniki badań pozwoliły na potwierdzenie postawionej we wprowadzeniu tezy, że możliwe jest wskazanie cech charakterystycznych kultury organizacyjnej organizacji chińskich. Wyniki przedstawione w tabelach 1-3 jednoznacznie wskazują na specyfikę tych organizacji. Dodatkowo potwierdzono tezę, że znajomość tych cech może przyczynić się do ułatwienia procesu dostosowania się organizacji $z$ innych rejonów świata poprzez wypracowanie odpowiednich mechanizmów współpracy (Obłój, 1999). Pozwoli to na lepsze wykorzystanie potencjału organizacji chińskich dla tworzenia przewag konkurencyjnych w strukturach wirtualnych.

Poza tym należy podkreślić, że dużą rolę w procesie osiągania spójności oraz w opracowaniu mechanizmów współpracy odgrywać powinny przedstawione wyniki badań dotyczące stanów oczekiwanych przez badanych pracowników - powinny one stanowić podstawę strategii współpracy tworzonych przez praktyków zarządzania, integratorów oraz gniazda w relacjach $\mathrm{z}$ ich dostawcami i klientami wewnętrznymi. Świadomość tych oczekiwań pozwoli na bezpośrednie uwzględnienie ich w tworzonych strategiach, co może spotkać się ze szczególnym uznaniem organizacji chińskich.

Odnosząc się bezpośrednio oraz szczegółowo do przedstawionych wyżej wyników badań, należy stwierdzić, że organizacje chińskie cechuje autorytarny, biurokratyczny oraz mocno hierarchiczny sposób funkcjonowania. Pracownicy traktowani są jako posłuszni wykonawcy rozkazów bez prawa do wyrażania własnych opinii. Dodatkowo, bardzo specyficzną cechą tych organizacji jest ogromna rola relacji nieformalnych i osobistych. Odgrywają one kluczową rolę dla wzajemnego zaufania i współpracy. Podsumowując wyniki badań w obszarze oczekiwanych kierunków zmian, warto zauważyć, że pracownicy zdają sobie sprawę z przedstawionego wyżej charakteru ich organizacji w badanych obszarach i jednocześnie postulują diametralną zmianę w kierunku podmiotowości pracowniczej, otwartości, możliwości partycypacji oraz sprawiedliwości i uczciwości w traktowaniu pracowników. W ramach dyskusji naukowej warto porównać te wyniki $\mathrm{z}$ badaniami innych autorów (Tsui i in., 2006; Jaw i in., 2007).

Należy zaznaczyć, że dla pełnego zrozumienia kultury organizacyjnej w Chinach konieczne jest wskazanie i pogłębiona analiza szerszego kontekstu funkcjonowania tego kraju jako całości. Zgodnie z tzw. konsensusem pekińskim, stanowiącym podstawę nowego modelu rozwoju kraju, wolnorynkowy rozwój gospodarczy oddzielony zostaje od liberalizacji politycznej (Jacques, 2012). Jednocześnie kapitalistycznemu modelowi rozwoju gospodarki nie towarzyszy demokracja, co sprzyja rozwojowi mechanizmów autorytarnych (Halper, 2010). Swoisty model koegzystencji sfery politycznej i gospodarczej zakłada $\mathrm{z}$ jednej strony przyzwolenie na bogacenie się społeczeństwa, wzrost poziomu życia oraz znaczenia kraju na arenie międzynarodowej, $\mathrm{z}$ drugiej jednak oznacza akceptację rządów autorytarnych (Góralczak, 2010; 2018). Chiński model rozwoju jest wyrazem unikalnego charakteru dominujących w społeczeństwie chińskim zasad konfucjańskich, demografii, filozofii rządzenia oraz relacji pomiędzy władzami oraz społeczeństwem (Kołodko, 2018). Nie jest przedmiotem niniejszego artykułu pogłębiona analiza szerszego kontekstu kulturowego Chin, należy jednak zaznaczyć konieczność jego zrozumienia dla wypracowania skutecznych mechanizmów współpracy z organizacjami chińskimi (Schell, Delury, 2013; Pimpaneau, 2018).

Poruszone $\mathrm{w}$ niniejszym artykule treści powinny stać się przyczynkiem do dalszych badań w zakresie koncepcji spójności (Flieger, 2018a). Jednym z ciekawych obszarów dalszych badań, posiadającym duży walor aplikacyjny, jest opracowanie konkretnych strategii współpracy, uwzględniając specyfikę funkcjonowania organizacji polskich oraz chińskich $\mathrm{w}$ zakresie różnic kulturowych. Zaproponowanie konkretnych mechanizmów skutkowałoby stworzeniem pewnego zbioru, z którego mogliby korzystać praktycy zarządzania. Takie rozwiązania stanowiłyby cenną pomoc chociażby w procesie harmonizowania kooperacji w ramach sieci międzyorganizacyjnych (Flieger, 2018b).

Dodatkowo warto prowadzić pogłębione badania dotyczące różnic kulturowych różnych obszarów świata, aby możliwe było sprawne i efektywne wykorzystanie zasobów (KCS), które w tych rejonach są zlokalizowane. Dużym wyzwaniem jest także opracowanie miar spójności organizacyjnej, co ułatwiłoby menedżerom jej bieżącą ocenę, analizę oraz wskazanie kierunków optymalizacji działań dla zapewnienia większej spójności. 


\section{dr hab. Michat Flieger, prof. UAM \\ Uniwersytet im. Adama Mickiewicza \\ Wydział Prawa i Administracji \\ ORCID: 0000-0002-8430-8883 \\ e-mail: m.flieger@wp.pl}

\section{dr Marcin Flieger \\ Akademia Wojsk Lądowych imienia \\ generała Tadeusza Kościuszki \\ Wydział Zarządzania \\ ORCID: 0000-0002-6810-7141 \\ e-mail: marcin.flieger@awl.edu.pl}

\section{Przypisy}

1) Publikacja powstała $w$ ramach stażu naukowego sfinansowanego w drodze konkursu ze środków statutowych Wydziału Prawa i Administracji im. Adama Mickiewicza w Poznaniu

2) Przy grupowaniu poziomów kultury organizacyjnej przyjęto koncepcję kultury odpowiadającą założeniom E. Scheina, tzw. koncepcję góry lodowej (Kopczewski i in., 2012, s. 123-140).

3) Wyniki badań dotyczące poziomu artefaktów kulturowych przedstawione zostały w publikacji M. Flieger, Spójność organizacyjna: harmonizacja wspólpracy $w$ aspekcie kultury organizacyjnej-perspektywa organizacji chińskich - artykuł w druku Wydawnictwa Akademii Wojsk Lądowych we Wrocławiu.

4) Wyniki badań dotyczące poziomu artefaktów kultury organizacyjnej przedstawione zostały $\mathrm{w}$ odrębnym opracowaniu znajdującym się w druku.

5) Patrz także wyniki innych badaczy: P. Leung (2006), S. Xu, R. Yang (2009), L. Wei (2008).

\section{Bibliografia}

[1] Borowski J. (2015), Globalizacja w świetle teorii ekonomii i teorii zarządzania, „Optimum. Studia Ekonomiczne”, $\mathrm{Nr}$ 6(78), s. 58-71.

[2] Czakon W. (2012), Sieci w zarzadzaniu strategicznym, Oficyna Wolters Kluwer Business, Warszawa.

[3] Flieger M. (2018a), Istota, zastosowanie oraz ocena empiryczna koncepcji spójności organizacyjnej, [w:] R. Kamiński (red.), Innowacje gospodarcze. Wybrane aspekty ekonomiczne i prawne, Wydawnictwo Naukowe UAM, Poznań, s. 231-249.

[4] Flieger M. (2018b), Uwarunkowania harmonizacji kooperacji $w$ ramach sieci międzyorganizacyjnej na poziomie gminnym, „Management Forum”, Tom 6, Nr 2, s. 8-15.

[5] Flieger M. (2017a), Innovative Consistency in Organizations - Business Process Management Perspective, „International Journal of Contemporary Management", No. 16/3, s. 125-139.

[6] Flieger M. (2017b), Virtual Structures in BPM as a Good Practice to Make Economic Ventures Effective - Research Results, International Forum: The Business Conditions and Legal Respect of Distribution in Asia, Korea Business and Law Administration, Seul, pp. 49-71.

[7] Flieger M. (2016), Koncepcja spójności organizacyjnej, Zeszyty Naukowe Politechniki Śląskiej, seria: Organizacja i Zarządzanie, Nr 2(34), s. 21-31.
[8] Flieger M., Turek D. (2016), Kultura organizacyjna w zarzadzaniu współczesnymi organizacjami, [w:] R. Kamiński, J. Sój$\mathrm{ka}$ (red.), Kulturowe uwarunkowania działalności gospodarczej, Polskie Towarzystwo Ekonomiczne, Poznań, s. 49-69.

[9] Flieger M. (2012), Zarzadzanie procesowe w urzędach gmin. Model adaptacji kryteriów dojrzałości procesowej, Wydawnictwo Naukowe UAM, Poznań.

[10] Flieger M. (2014), Planowanie i organizowanie systemu zarzadzania wizerunkiem organizacji, „Marketing i Rynek”, Nr 5, s. 331-338.

[11] Góralczak B. (2018), Wielki renesans, Dialog, Warszawa.

[12] Góralczak B. (2010), Wokół chińskiego modelu rozwojowego, http//polska-azja.pl, s. 90, data dostępu: 02.01.2019.

[13] Halper S. (2010), The Bejjing Consensus: How China's Authoritarian Model Will Dominate Twenty First Century, New York.

[14] Jacques M. (2012), When China Rules The World: The End of The Western World and The Birth of The New Global Order, New York.

[15] Jaw B., Ling Y., Wang C. (2007), The Impact of Culture on Chinese Employees' Work Values, „Personnel Review”, No. 36(1), pp. 128-144.

[16] Kołodko G. (2018), Czy Chiny zbawią świat, Prószyński i S-ka, Warszawa.

[17] Kopczewski M., Pączek B., Tobolski M. (2012), Istota kultury organizacyjnej w zarzadzaniu przedsiębiorstwem produkcyjnym, „Edukacja Ekonomistów i Menedżerów: Problemy, Innowacje, Projekty", Nr 4(26), s. 123-140.

[18] Leung P. (2006), Cultural Impact On Chinese Corporate Disclosure - A Corporate Governance Perspective, Emerald Publishing, pp. 241-264.

[19] Mayne J., Wileman T., Leeuw F. (2003), Networks and Partnering Arrangements: New Challenges for Evaluation and Auditing, [in:] A. Gray, B. Jenkins, F. Leeuw, J. Mayne (eds.), Collaboration in Public Services: The Challenge for Evaluation, New Brunswick.

[20] Obłój K. (2009), Znaczenie spójności strategii, „Przegląd Organizacji”, Nr 9, s. 6-8.

[21] Obłój K. (1999), Strategia organizacji, PWE, Warszawa.

[22] Perechuda K. (2000), Zarządzanie przedsiębiorstwem przyszło$s ́ c i$, Difin, Warszawa.

[23] Pierścionek Z. (2003), Strategie konkurencji i rozwoju przedsiębiorstwa, Wydawnictwo Naukowe PWN, Warszawa.

[24] Pimpaneau J. (2018), Chiny. Kultura i tradycje, Wydawnictwo Akademickie Dialog, Warszawa.

[25] Schell O., Delury J. (2013), Wealth and Power: China's March to the Twentieth Century, New York.

[26] Sułkowski Ł. (2013), Konsumpcjonizm z perspektywy krytycznego nurtu zarządzania, „Polityki Europejskie, Finanse i Marketing", Nr 10(59), s. 684-693.

[27] Tsui A., Wang H., Xin K. (2006), Organizational Culture in China: An Analysis of Culture Dimensions and Culture Types, „Organization and Management Review”, No. 2(3), pp. 345-376.

[28] Wei L. (2008), The Role of Corporate Culture in the Process of Strategic Human Resource Management: Evidence from Chinese Enterprises, „Human Resource Management”, Vol. 47, No. 4, Winter, pp. 777-794.

[29] Xu S., Yang R. (2009), Indigenous Characteristics of Chinese Corporate Responsibility Conceptual Paradigm, „Journal of Business Ethics", Vol. 10/93, pp. 321-333. 


\section{Elements of Corporate Culture of Chinese Organizations in the Perspective of Virtual Structures Consistency}

\section{Summary}

Opening borders makes it possible for organisations to use critical success factors of organisations operating in areas of the world which have been closed so far. One of such areas is China and organisations which operate there. The article focuses on consistency concept in terms of corporate culture. Corporate culture is one of the main characteristics of each organisation and it is crucial to recognise cultural traits in order to match cooperation mechanisms accord- ingly. In the article its authors present the results of the research regarding corporate culture of Chinese organisations. The results have shown that these organisations are highly autocratic with main role of orders and workers subordination. In the same time the research has shown that Chinese workers would like to see a change in the way their corporate culture looks like. This knowledge may be used by organisations from different parts of the world to adjust to their Chinese partners to sustain consistency.

\section{Keywords}

consistency concept, corporate culture, consistency platforms, virtual structures 